\title{
MORAL POLITIK GERAKAN MAHASISWA DALAM PERSPEKTIF TINJAUAN FILOSOFIS HUKUM ISLAM
}

\author{
Rizal Al-Hamid \\ UIN Sunan Kalijaga Yogyakarta \\ rizal.alhamid@uin-suka.ac.id
}

\begin{abstract}
The dynamics of the student movement is a study that will not be interrupted and very interesting. It is a reality both from a historical perspective and in the context of reality that the dynamics of student movements have provided a phenomenon that continues as if it had no end. However the student movement has colored various political events in Indonesia. This is what sometimes does not bring a productive solution This paper aims to discuss some philosophies of Islamic teachings that can be a reference in the student movement.
\end{abstract}

Keyword: Political Morals, Student Movement, Islamic LaW

\begin{abstract}
ABSTRAK
Dinamika gerakan mahasiswa adalah studi yang akan terus beralngsung dan menarik untuk dibahas. Hal tersebut menjadi sebuah realitas tertentu baik dari perspektif sejarah maupun dalam konteks realitas bahwa dinamika gerakan mahasiswa tersebut telah pula menjadi fenomena yang terus berlanjut dan sepertinya tidak akan pernah berakhir. Tidak bisa dipungkiri bahwasannya pergerakan mahasiswa telah mewarnai berbagai peristiwa politik di Indonesia. Dalam hal inilah terkadang dinamika pergerakan tersebut alih-alih membawa solusi produktif, namun sebaliknya. Makalah ini bertujuan untuk membahas beberapa pandangan filosofis dan perspektif baru dalam ajaran dan hukum Islam yang dapat dijadikan sebagai rujukan oleh gerakan mahasiswa tersebut.
\end{abstract}

Kata Kunci: Moral Politik, Gerakan Mahasiswa, Hukum Islam

\section{PENDAHULUAN}

Gerakan mahasiswa identik dengan gerakan yang begitu massif serta berperan besar dalam rangka mengoreksi adanya disorientasi sosial dan politik. Gerakan mahasiswa ini biasanya ada di pihak rakyat dan membela kepentingan rakyat. Pembelaan mahasiswa tersebut biasanya seputar penindasan dan atas dasar nilai keadilan yang secara idealis dipegang oleh mahasiswa. Konteks tersebut menjadi pemicu utama kuatnya gerakan sosial dan identitas gerakan tersebut pada gerakan mahasiswa sehingga dapat menjadi kekuatan penyeimbang dalam proses perubahan yang terjadi di masyarakat. Sejarah mencatat setidaknya gerakan mahasiswa memberi andil yang sangat besar pada beberapa proses dan dinamika transisi di negara Indonesia.

Biasanya segala bentuk perlawanan dan gerakan yang dilakukan oleh mahasiswa dengan segala maneuver organisasinya adalah dalam kerangka melakukan kritik atau 
koreksi atas perilaku-perilaku politik penguasa yang mereka rasakan telah mengalami distorsi dan disorientasi yang sudah jauh dari komitmen awal politik penguasa dalam melakukan serangkaian perbaikan bagi kesejahteraan hidup rakyatnya atau telah mengingkari janji politik yang dibuatnya. Oleh sebab itulah, peranan gerakan mahasiswa menjadi begitu penting dan berarti dalam dinamika kehidupan masyarakat utamanya dalam rangka membela hak dan keadilan mereka. Bahkan, jika kita cermati bersama sejarah perjalanan sebuah bangsa di beberapa negara di dunia mencatat bahwa perubahan sosial atau social change yang terjadi hampir sebagian besar dipicu dan dipelopori oleh gerakan perlawanan yang dilakukan oleh mahasiswa. ${ }^{1}$

Peran gerakan mahasiswa tersebut sebagai pelopor dan penggerak dalam membela rakyat dari adanya tirani politik penguasa dan segala bentuk ketimpangan yang terjadi di level grassroot masyarakat Indonesia. Mahasiswa dan gerakannya memang senantiasa mengusung panji-panji keadilan, kejujuran, serta selalu hadir dengan ketegasan dan keberaniannya. Meskipun memang tak bisa dipungkiri, faktor pemihakan mahasiswa terhadap ideologi tertentu turut dalam mewarnai aktifitas politik mahasiswa yang telah memberikan kontribusinya yang cukup besar dari kekuatan politik serta sebagai politik penyeimbang yang lebih dominan. Mahasiswa merupakan sosok pertengahan dalam masyarakat yang idealis meskipun pada realitasnya terkadang harus keluar dari idealitasnya gerakan dan pemikirannya. Pemihakan gerakan mahasiswa terhadap ideologi tertentu dalam memang sulit untuk bisa dihindari. Hal tersebut memang bukan sebuah kenyataan yang mengherankan karena pada diri mahasiswa terdapat sifat-sifat intelektualitas serta mampu bersikap kritis dan merdeka, berani menyatakan kebenaran apa adanya sesuai dengan prinsip yang mereka pedomani. Hal tersebut menjadi sebuah racikan konsep yang cukup ideal bagi sebuah pergerakan mahasiswa meskipun tak jarang pemihakan-pemihakan tersebut tidak pada tempatnya. ${ }^{2}$

Jika kita lihat sejarah gerakan mahasiswa dan pemuda di Indonesia, kita akan melihat peran penting yang selalu dimainkannya ketika Indonesia sedang mengalami keadaan kritis baik secara politik, ekonomi maupun tatanan sosial. Kita ambil contoh misalnya para pemuda, termasuk di dalamnya adalah mahasiswa, merupakan pencetus

${ }^{1}$ Evyta A. R. Gerakan Mahasiswa antara Idealitas dan Realitas (Medan: KAMMI, 2005), 2. ${ }^{2}$ Ibid., 3 . 
Sumpah Pemuda 1928. Peran mereka juga terlihat misalnya dalam gerakan untuk memperjuangkan kemerdekaan sebelum tahun 1940 dan ketika revolusi kemerdekaan tahun 1945 digaungkan oleh para founding father kita. (Sebagai catatan Soekarno dan Hatta pada waktu itu diculik oleh para pemuda dan dibawa ke Rengasdengklok untuk “dipaksa" membacakan Proklamasi Kemerdekaan bangsa tanggal 17 Agustus 1945). Gerakan para pemuda kemudian muncul lagi pada tahun 1966 dan yang cukup menarik perhatian adalah, meminjam istilah Arief Budiman, sebagai bintang lapangan dalam peristiwa reformasi 1998 dalam menggulingkan Rezim Soeharto. ${ }^{3}$

Salah satu peristiwa sejarah adalah peristiwa 1998 dimana saat itu barisan mahasiswa sukses menumbangkan Presiden Soeharto dan menaklukkan Orba, semakin mengukuhkan bahwa predikat mahasiswa adalah sebagai agent of change. Adapun tumbangnya Soeharto merupakan buah efek domino dari beberapa peristiwa gerakan mahasiswa, mulai angkatan 74, 77/1978, 80-an dan 90-an. Gerakan tersebut didukung oleh elemen pro demokrasi lainnya. Masing-masing angkatan gerakan mahasiswa sedikit banyak berkontribusi dalam perjuangan melengserkan kekuasaan tirani Soeharto. Pada masa angkatan 74, gerakan mahasiswa sudah mulai muncul dengan melakukan kritik terhadap kinerja pemerintahan Soeharto.

Gerakan mahasiswa angkatan $77 / 78$, sudah menyuarakan perlunya meminta tanggung jawab Soeharto sebagai Presiden. ${ }^{4}$ Berbeda dengan mahasiswa angkatan 98, gerakan mahasiswa sebelumnya sulit mencari kemenangan politis karena perlawanan mereka tidak sebanding dengan kekuatan politik yang dimainkan oleh Orba. Sebab itulah, mahasiswa generasi 1998 sering disebut sebagai "generasi pemetik bunga." Keberhasilan mereka dimungkinkan oleh matangnya situasi pada saat itu, dimana mereka didukung oleh kondisi krisis ekonomi dan krisis moneter, selain itu mereka juga didukung oleh menghangatnya konflik politik antara elit dan juga dudukung dengan situasi memanasa seputar delegitimasi rezim. Disamping itu dukungan yang luas dari hampir seluruh elemen rakyat juga memberikan suntikan moral tersendiri. ${ }^{5}$

3 Arief Budiman, Dalam Arbi Sanit. Pergolakan Melawan Kekuasaan: Gerakan Mahasiswa Antara Aksi Moral dan Politik (Yogyakarta: Pustaka Pelajar Offset, 1999), Xii.

4 Edy Budiyarso. Menentang Tirani: Aksi Mahasiswa 77/78 (Jakarta: Grasindo, 2000), 32.

5. A. Prasetyantoko \& Indrio, Ign. Wahyu, dkk. Gerakan Mahasiswa dan Demokrasi di Indonesia. (Jakarta: Kompas, 2001), 75. 
Jatuhnya Soeharto pada masa itu bukanlah menjadi tujuan akhir perjuangan dan pergerakan yang dilakukan oleh mahasiswa. Akan tetapi keyakinan mahasiswa yang menjadikan Soeharto sebagai pusat segala persoalan dan huru-hara yang terjadi di Indonesia, maka jatuhnya Soeharto berarti adalah pencapaian tertentu untuk menggapai perubahan yang telah mereka gaungkan sejak lama. Sementara itu gelombang pergerakan mahasiswa sejak era transisi terus berlanjut tanpa henti, meskipun fakta historisnya gelombang tersebut mengalami pasang dan surut. Adapun pada masa pemerintahan Presiden Habibie, muncul resistensi gerakan mahasiswa yang masih berada dalam gelombang pasang dan akibat masa transisi kepimpinan. Meskipun begitu, adanya masa transisi kepemimpinan membuat skala keterlibatan mahasiswa dalam beberapa aksi telah menyusut secara signifikan. Peran mahasiswa pada masa penggulingan Soeharto yang melibatkan seluruh komponen mahasiswa di Indonesia secara massif telah surut. Sisa dari pergerakan tersebut kemudian hanyalah sebagian kecil gerakan mahasiswa, yang pada saat itu tersebar di sejumlah kota di mana Jakarta menjadi kota yang paling dominan.

Namun, kenyataan sejarah yang kemudian terjadi adalah semangat perjuangan mahasiswa pada era transisi yang menyurut cukup besar jika dibandingkan gerakan mahasiswa sebelumnya. Gerakan mahasiswa mengalami disorientasi, fragmentasi, dan berkurangnya militansi serta adanya friksi di mana mana. Penyebab adanya disorientasi terutama adalah karena raibnya common enemy (Soeharto) atau musuh utama yang memang faktanya menjadi factor paling dominan yang menyatukan mereka. Setelah Soeharto runtuh dan terguling, gerakan mahasiswa kehilangan isu sentral dan isu besar bahkan untuk sekedar menjaga jalinan kebersamaan yang sudah lama terbangun ketika gigih menjungkalkan Soeharto.

Adapun Amien Rais menilai bahwasannya gerakan mahasiswa pasca kejatuhan rezim Soeharto yang selama masa itu terkonsolidasi dengan baik telah mengalami perubahan dan penyurutan yang sangat abesar, perubahan yang oleh Amin Rais dikatakan justru tidak menuju ke arah yang gerakan mahasiswa yang lebih baik justru sebaliknya menjadi titik balik menjadi vakumnya gerakan mahasiswa di Indonesia. Menurut Amin Rais gerakan mahasiswa yang kini terjadi dan muncul secara sporadic di beberapa wilayah di Indonesia hanyalah gerakan yang mati suri. Aksi-aksi demonstrasi 
besar yang dulu dilakukan dalam menyikapi kebijakan pemerintah kini tak lagi banyak digelar. Mahasiswa lebih banyak vakum. ${ }^{6}$ Informasi yang sering diberitakan di media massa memang mangabarkan ada kecenderungan yang menurun bila dilihat dari kuantitas dan kualitas aksi mahasiswa yang digelar. Berdasarkan penelurusan dan dokumentasi media yang tersaji di media massa, aksi-aksi mahasiswa sangatlah menyeruak menjelang era reformasi.

Kuantitas massa aksi mahasiswa yang tercatat oleh media massa misalnya antara 100 bahkan sampai 50.000 orang (penulusuran Kompas tahun 1998). Bahkan menjelang era reformasi, kelompok masyarakat dan beberapa kalangan elite politik pun juga turut mendukung bahkan ikut turun ke jalan memberikan support moril terhadap gerakan tersebut. Sebagai contohnya adalah aksi gerakan mahasiswa Universita Indonesia pada tanggal 25 Februari 1998 yang diikuti oleh banyak sesepuh UI dan bahkan dihadiri juga oleh beberapa Guru Besar UI. ${ }^{7}$ Contoh lain adalah aksi dan gerakan yang dilakukan oleh mahasiswa Unair pada tanggal 28 Februari 1998 yang juga dihadiri oleh Guru Besar serta Pengajar dan dosen di salah satu kampus terbesar di Surabaya tersebut. ${ }^{8}$

Adapun pasca reformasi, gerakan mahasiswa tersebut secara praktis terjadi tidak hanya penurunan jumlah massa aksi melainkan pula kualitas aksi dan gerakan mahasiswa itu sendiri. Sebagai contoh misalnya berdasarkan penelurusan dokumentasi media massa antara edisi pasca tahun 1998, terhitung jumlah massa aksi yang turut menjadi peserta hanya antara 50 sampai 1500 orang dan bahkan bisa jadi lebih sedikit dari itu. Secara kualitas aksi yang mereka selenggarakan juga cenderung tidak didukung oleh masyarakat dan politisi, bahkan aksi tersebut terkesan merugikan bagi masyarakat.

Sebagai contoh pula misalnya pemberitaan media massa mengenai penyanderaan mobil tangki yang dilakukan oleh oknum mahasiswa dalam gerakan mahasiswa yang terjadi Sulawesi sebagai salah satu bentuk aksi dalam menolak kenaikan harga BBM pada tanggal 26 Januari 2002, hal tersebut menjadi catatan tersendiri karena aksi yang merak lakukan merepotkan warga dan tidak berdampak signifikan terhadap perubahan yang terjadi di masyarakat. ${ }^{9}$ Catatan media massa pula yang memberitakan bahwa

\footnotetext{
6. Kompas, 19 Desember 2005

7. Kompas, 25 Februari 1998

8. Kompas, 29 Februari 1998

9. Kompas, 27 Januari 2002
} 
sempat terjadi adanya aksi yang kontra produktif dengan awak media semisal adanya kasus penyekapan terhadap empat wartawan yang dilakukan oleh oknum mahasiswa yang terjadi pada aksi dan gerakan mahasiswa di Yogyakarta pada tanggal 29 Agustus $2002 . .^{10}$

Amien Rais merupakan salah satu tokoh yang terlibat langsung dalam proses reformasi 1998, oleh karena itu sangat bisa dimengerti bila ia merasa gelisah dengan perkembangan gerakan mahasiswa akhir-akhir ini yang dinilai kurang positif jika dibandingkan pada era sebelumnya. Kegelisahan yang dirasakan oleh Amin Rais atas menurunnya aktifitas gerakan mahasiswa tersebut dirasakan pula oleh tokoh lain dan aktivis yang pernah terlibat langsung dalam menurunkan rezim Soeharto serta dirasakan oleh para aktivis gerakan mahasiswa yang masih terlibat aktif dalam berorganisasi. Apa yang disampaikan oleh Amin Rais dan beberapa tokoh tersebut mempertegas bahwasannya selain pihak "luar," banyak aktivis senior gerakan mahasiswa sendiri yang juga turut merasakan adanya penurunan aktivistas gerakan kemahasiswaan utamanya di era pasca reformasi. Salah satu pengamatan yang disampaikan oleh Amien Rais dalam menyimpulkan hal tersebut adalah gelagat gerakan mahasiswa yang seolah-olah mati suri dan hal tersebut tertuju pada kuantitas aksi gerakan mahasiswa yang makin menurun pada era reformasi dan era pasca reformasi ini.

Disamping itu, kualitas dari aksi-aksi yang digelar oleh mahasiswa juga nyatanya perlu dicermati. Hal tersebut penting untuk dilakukan karena manakala indikator yang digunakan unt uk menilai aktivisme mahasiswa hanya terbatas pada jumlah demonstrasi yang mereka lakuka dalam periode tertentu, maka yang fakta yang nampak dalam dinamika gerakan mahasiswa tidak akan seluruhnya tertangkap. Sederhananya indicator dari banyaknya aksi bisa jadi tidak menggambarkan realitas sesungguhnya dari dinamika gerakan mahasiswa tersebut terutama di era keterterbukaan semacam ini untuk menyuarakan aspirasinya, kesimpulan yang bias akan terjadi bila kita hanya mengukur kondisi gerakan mahasiswa hanya pada kuantitas aksi demonstrasinya saja.

Kajian seputar dinamika pergerakan mahasiswa adalah suatu kajian yang akan terus berlanjut dan menarik dicermati. Dari perspektif sejarah maupun dalam konteks realita kita ketahui bahwa dinamika pergerakan mahasiswa telah memberikan fenomena

10. Kompas, 28 Agustus 2002 
yang berlangsung terus-menerus seolah tidak berujung. Bagaimanapun gerakan mahasiswa juga merupakan kampus rakyat, yang telah mewarnai dinamika berbagai peristiwa politik yang terjadi di Indonesia. Hal inilah yang sering tidak membawa penyelesaian yang produktif. Artikel ilmiah ini memfokuskan kajiannya pada gerakan mahasiswa dan bagaimana Islam secara filosofis dan hukum memandang gerakan mahasiswa tersebut.

Gerakan mahasiswa sering disebut sebagai gerakan moral, mereka bergerak biasanya untuk memperjuangkan aspirasi dari rakyat. Akan tetapi hari-hari ini yang terjadi gerakan mahasiswa ternyata kalah dengan gerakan buruh yang memang lahir dari rahim rakyat, bahkan lebih dari itu yang lebih dominan adalah gerakan organisasi masyarakt. Gerakan mahasiswa kini tak terdengar lagi keberadaannya, justru masyarakat kian apatis dan tidak sedikit pula yang faktanya membubarkan aksi mahasiswa karena merasa terganggu. Pertanyaannya adalah apakah gerakan mahasiswa sekarang ini yang memang kurang diminati, atau memang gerakan tersebut telah pindah ke media sosial?

Mungkinkah mahasiswa dalam gerakannya tersebut hanyalah suatu bentuk drama semata? Pertanyaan mendasar lain yang patut kita pertanyakan adalah "Apa alasannya mahasiswa melakukan gerakan tersebut? Apakah mereka bergerak hanya mencari sensasi atau memang karena ada oknum yang menggerakkan mereka? Mungkinkah mahasiswa bergerak karena memenuhi tuntutan pasar? Serangkaian pertanyaan ini tidak hanya menjadi pertanyaan klise, dibalik itu semua terkandung suatu makna yang sangat mendalam.

\section{RUANG LINGKUP TEORI GERAKAN MORAL}

\section{Teori Konstruktivisme}

Konstruktivisme merupakan suatu cabang filsafat yang menekankan pengertian bahwa pengetahuan adalah bentukan (konstruksi) kita sendiri. Dalam pandangan Konstruktivisme, pengetahuan bukanlah tiruan dari realitas, bukan pula gambaran dari dunia kenyataan yang ada. Pengetahuan merupakan hasil dari konstruksi kognitif melalui kegiatan seseorang dengan membuat struktur, kategori, konsep, dan skema yang diperlukan untuk membentuk pengetahuan tersebut. Konstruktivisme merupakan landasan berpikir (filosofi) pembelajaran konstektual yaitu bahwa pengetahuan 
dibangun oleh manusia sedikit demi sedikit, yang hasilnya diperluas melalui konteks yang terbatas dan tidak sekonyong-konyong. Pengetahuan bukanlah seperangkat faktafakta, konsep, atau kaidah yang siap untuk diambil dan diingat. Manusia harus mengkontruksi pengetahuan itu dan memberi makna melalui pengalaman nyata. Vygotsky, yang menyatakan bahwa siswa dalam mengkonstruksi suatu konsep perlu memperhatikan lingkungan sosial. Konstruktivisme ini oleh Vygotsky disebut konstruktivisme sosial.

Pendekatan yang mengacu pada konstruktivisme sosial (filsafat konstruktivis sosial) disebut pendekatan konstruktivis sosial. Filsafat konstruktivis sosial memandang kebenaran matematika tidak bersifat absolut dan mengidentifikasi matematika sebagai hasil dari pemecahan masalah dan pengajuan masalah (problem posing) oleh manusia. Dalam pembelajaran matematika, Cobb, Yackel dan Wood menyebutnya dengan konstruktivisme sosio (socio-constructivism), siswa berinteraksi dengan guru, dengan siswa lainnya dan berdasarkan pada pengalaman informal siswa mengembangkan strategi-strategi untuk merespon masalah yang diberikan. Pemahaman orang tentang konstruktivisme beragam. Hal ini terjadi karena konstruktivisme memang mempunyai beberpa perwujudan tergandtung dari sisi mana dilihatnya. Untuk dapat memahami perspektif konstruktivisme dengan utuh kita perlu membahas dua sisi bentuk konstruktivisme, yaitu konstruktivisme individual(individual constructivism) dan konstruktivisme social (social constructivism)

Sebagaimana diketahui bahwa menurut pandangan konstruktivis, suatu pengetahuan dibangun sendiri oleh siswa dengan menggunakan pengalaman dan struktur kognitif yang sudah dimiliki. Akan tetapi, hal ini tidaklah berarti tidak dimungkinkannya pemahaman bersama atau pemahaman yang sama terhadap suatu realitas. Sekelompok orang dapat mempunyai pemahaman yang sama terhadap suatu fenomena atau realitas tertentu melalui interaksi sosial dan kolaborasi bersama dalam membangun makna. Penjelasan tersebut selaras dengan teori yang dikemukakan oleh Piaget dan Vygotsky dalam menjelaskan tentang "belajar". ${ }^{11}$

Vygotsky adalah seorang psikolog dari Rusia yang juga penganjur konstruktivisme selain Piaget. Vygotsky berpendapat bahwa pengetahuan dibangun

\footnotetext{
${ }^{11}$ Ida Bagus Putrayasa, Landasan Pembelajaran (Bali: Undiksha Press, 2012), 90.
} 
secara sosial, dalam arti bahwa peserta yang terlibat dalam suatu interaksi sosial akan memberikan kontribusi dan membangun bersama makna suatu pengetahuan. Dengan demikian, proses yang terjadi akan beragam sesuai dengan konteks kulturalnya.

Proses dan konteks cultural yang beragam juga menghasilkan "belajar"e yang bergam pula. Misalnya, seorang anak yang mendengarkan cerita dari orang tuanya sebelum tidur akan berbeda dengan anak yang lebih mengandalkan tayangan televisi dalam memahami nilai-nilai tertentu. Besar kemungkinan pemahaman anak terhadap suatu nilai sebagai hasil "belajar"e tidak akan sama melalui kedua proses yang berbeda tersebut. Belajar menurut pandangan konstruktivis lebih diarahkan pada terbentuknya makna pada diri pemelajar atas apa yang dipelajarinya berdasarkan pengetahuan dan pemahaman mereka sebelumnya. Dalam proses ini lebih ditekankan pada terbentuknya hubungan-hubungan makna antara pengetahuan yang telah ada dan pengetahuan baru dengan fasilitasi kreativitas guru selaku mediator pembelajaran. Aplikasi model konstruktivis memungkinkan siswa untuk menguasai materi pelajaran secara lebih komprehensif dan bermakna, mengingat mereka terlibat secara aktif selama berlangsungnya pembelajaran. Faham konstruktivis memandang bahwa pengetahuan merupakan konstruksi (bentukan) dari orang yang mengenal sesuatu (skemata). Pengetahuan tidak bisa ditransfer dari guru kepada orang lain, karena setiap orang mempunyai skema sendiri tentang apa yang diketahuinya. ${ }^{12}$

Pandangan konstruktivisme tentang pengetahuan secara sederhana dapat dirangkum sebagai berikut:(1) kita tidak bisa mengetahui suatu kenyataan yang objektif; (2) pengetahuan adalah subjektif; dan (3) Pengetahuan dari dua orang bias dikatakan saling berbagi sepanjang pembentukannya dilakukan dengan cara yang sama dalam situasi tertentu. Hal paling penting dalam teori konstruktivisme adalah penekakan pada siswa dalam proses pembelajaran. Mereka yang harus bertanggung jawab terhadap hasil belajarnya. Belajar lebih diarahkan pada experiental learning, yaitu adaptasi kemanusiaan berdasarkan pengalaman konkret di laboratorium, diskusi dengan teman sejawat, yang kemudian dikontemplasikan dan dijadikan ide serta pengembangan konsep baru. Terdapat beberapa kemampuan yang diperlukan dalam proses mengkonstruksi pengetahuan, yaitu; (1) kemampuan mengingat dan mengungkapkan kembali

\footnotetext{
${ }^{12}$ Ida Bagus Putrayasa, Landasan Pembelajaran, 91-92.
} 
pengalaman, (2) kemampuan membandingkan dan mengambil keputusan akan persamaan dan perbedaan, dan (3) kemampuan untuk lebih menyukai suatu pengalaman yang satu daripada yang lainnya.

Aspek-aspek konstruktivisme teridiri atas adaptasi (adaptation), konsep pada lingkungan (the concept of environment), dan pembentukan makna (the construction of meaning). Menurut Piaget, adaptasi terhadap lingkungan dilakukan melalui dua proses, yaitu asimilasi dan akomodasi. Bila dalam proses asimilasi seseorang tidak dapat mengadakan adaptasi terhadap lingkungannya maka terjadilah ketidaksetimbangan (disequilibrium). Tingkatan pengetahuan atau pengetahuan berjenjang oleh Vygotskian disebut sebagai scaffolding. Scaffolding berarti memberikan sejumlah besar bantuan kepada seorang individu selama tahap-tahap awal pembelajaran dan kemudian mengurangi bantuan tersebut dan memberikan kesempatan kepada individu tersebut mengambil alih tanggung jawab yang semakin besar segera setelah mampu mengerjakan sendiri.

Karakteristik yang juga merupakan prinsip dasar konstruktivisme meliputi: pengembangan strategi alternative untuk memperoleh dan menganalisis informasi, dimungkinkannya perspektif jamak dalam proses belajar. Peran utama siswa dalam proses belajar, penggunaan scaffolding dalam pembelajaran, peran guru sebagai fasilitator, tutor, dan mentor, pentingnya kegiatan belajar dan evaluasi belajar yang otentik. $^{13}$

\section{Gerakan Moral}

Dalam karyanya La Trahison des Clercs $^{14}$, Julian Benda menggambarkan cendekiawan sebagai sosok manusia ideal yang berprinsip "kerajaanku bukan di bumi ini”. Artinya para cendekiawan dikonstruksi sebagai manusia yang tidak memiliki kepentingan duniawi. Para cendekiawan yg terlibat dalam dunia perpolitikan, bagi Julian Benda dilihat sebagai wujud dari "Penghianatan Intelektual". Benda ingin mengatakan bahwa para cendekiawan ideal zaman dulu adalah moralis yang kegiatannya merupakan

\footnotetext{
${ }^{13}$ Ida Bagus Putrayasa, Landasan Pembelajaran, 93.

${ }^{14}$ Diterjemahkan dalam bahasa Indonesia; "Penghianatan Kaum Intelektual”, dalam Arif Novianto. 2013. Artikel ini dikembangkan dari diskusi MAP Corner-Klub MKP "Lumpuhnya Gerakan Mahasiswa", dengan pemantik Eko Prasetyo (Social Movement Institute), dalam Agus Pramusinto \& Yuyun Purbokusumo. 2016. Indonesia Begerak 2. Yogyakarta: Institute of Governance and Public Affair (IGPA) Magister Administrasi Publik (MAP) Universitas Gadjah Mada, 196.
} 
perlawanan terhadap realism massa.Karya Julian Benda tentang "Penghianatan Kaum Intelektual" ini merupakan pondasi dari gerakan moral di Indonesia. ${ }^{15}$

Membedakan apa itu gerakan moral dan apa itu gerakan politik progresif tanpa melihat latar belakang sejarah terbentuknya kedua gerakan tersebut dan factor ideologisnya, maka akan sulit untuk membedakannya serta akan cenderung mendistorsi pemaknaan kedua gerakan tersebut. Gerakan moral sebagai gerakan yang meletakkan energi mahasiswa hanya sebagai pendobrak ketika institusi birokrasi dan institusi politik tidak dapat memainkan peran sesuai dengan tuntutan sektor publik, gerakan tersebut hanya untuk meluruskan. ${ }^{16}$

Gerakan moral juga merupakan gerakan politik, namun bersifat regresif, kemudian dinamakan gerakan moral. Batasan gerakan moral adalah; pertama, gerakan moral menolak membangun aliansi dengan gerakan rakyat atau politik massa. Kedua, gerakan moral berdalih tidak ada ambisi dan kepentingan pribadi ataupun kelompok terhadap kekuasaan. Ketiga, gerakan moral dalam gerakannya lebih berupa tuntutan koreksi dan peringatan. Keempat, gerakan moral mengkonstruksi diri mereka sebagai resi, agent of change, tulang punggung negara, intelektual pembaharu, roda perubahan dan konstruksi heroism yang lainnya. ${ }^{17}$

Gerakan moral memang menjadi arena yang selaras dengan ideologi kelas menengah yang memang merupakan mayoritas mahasiswa. Pengetahuan dan intelektualisme mereka merupakan produk dari relasi produksi kapitalisme yang bertranformasi mendukung hirarki pengetahuan diantara mereka. Mahasiswa menjadi kelompok yang lebih maju dan memiliki ruang untuk merespon berbagai persoalan social dan politik. Dengan kekuatan moral, mereka juga tidak jarang melakukan aksi massa dan berbagai bentuk protes yang lain. Tuntutan politis mereka juga mengarah ke tendensi pembebasan sosial dan pembelaan terhadap kelas bawah atau tentang pembelaan moral terhadap kesewenang-wenangan organ negara. ${ }^{18}$

\footnotetext{
${ }^{15}$ Arif Novianto, Lumpuhnya Gerakan Mahasiswa",197.

${ }^{16}$ Sunyoto Usman. 1999. Arah Gerakan Mahasiswa: Gerakan Moral ataukah Gerakan Politik. Jurnal Imu Sosial \& Ilmu Politik, vol. 3, no. 2: pp. 146-163, dalam dalam Agus Pramusinto \& Yuyun Purbokusumo, Indonesia Begerak 2, (Yogyakarta: Institute of Governance and Public Affair (IGPA) Magister Administrasi Publik (MAP) Universitas Gadjah Mada, 2016), 197.

${ }^{17}$ Ibid, 198.

${ }^{18}$ Ibid., 199.
} 
Gerakan mahasiswa terbagi menjadi dua yakni: pertama, gerakan mahasiswa bersatu dengan rakyat, dimana gerakan mahasiswa harus berbentuk sebagai gerakan politik, dengan tujuan rakyat diajak berperan serta dalam merebut kekuasaan yang menjadi milik mereka dari tangan penguasa, yang dianggap tidak memperhatikan kehendak rakyat. Kedua, gerakan mahasiswa tetap dilakukan oleh mahasiswa sendiri dan membiarkan gerakan berjalan secara alami. Hal inilah merupakan gerakan moral, dengan mengutarakan kebenaran dan keadilan, dan tidak mempunyai ambisi untuk bermain kekuasaan atau dimainkan oleh individu atau kelompok yang berada di belakang gerakan tersebut. Oleh sebab itu, gerakan mahasiswa jenis ini bersifat "koreksi" terhadap penyimpangan-penyimpangan yang dilakukan oleh di penguasa. ${ }^{19}$

Pada hakekatnya gerakan mahasiswa bersifat anti kekerasan.Kekerasan bukanlah ciri gerakan mahasiswa di belahan bumi manapun. Watak gerakan mahasiswa lebih sebagai gerakan pemikiran kearah perubahan-perubahan yang evolutif menuju perubahan. Artinya yang ditonjolkan oleh gerakan mahasiswa adalah kualitas gagasan perubahan yang dihendaki dengan cara-cara yang lebih logis-intelektual. ${ }^{20}$ Gerakan mahasiswa mengaktualisasikan potensinya melalui sikap-sikap dan pernyataan yang bersifat imbauan moral. Mereka mendorong perubahan dengan mengetengahkan isu-isu moral sesuai sifatnya yang bersifat ideal. Ciri khas gerakan mahasiswa ini adalah mengaktualisasikan nilai-nilai ideal mereka karena ketidakpuasan terhadap lingkungan sekitarnya. $^{21}$

Gerakan moral ini diakui yang menilai sebenarnya sikap moral mahasiswa lahir dari karakteristiknya mereka sendiri. Mahasiswa sering menekankan peranannya sebagai "kekuatan moral" dan bukannya "kekuatan politik".22 Aksi protes yang dilancarkan mahasiswa berupa demonstrasi di jalan dinilai juga sebagai sebuah kekuatan moral karena mahasiswa bertindak tidak seperti organisasi sosial politik yang memiliki kepentingan praktis. Konsep gerakan moral bagi gerakan mahasiswa pada dasarnya adalah sebuah konsep yang menganggap gerakan mahasiswa hanyalah merupakan

\footnotetext{
${ }^{19}$ Suwondo, Gerakan Mahasiswa Bandar Lampung, (Jakarta: Bidang Studi Ilmu Politik Program Pasca Sarana Fakultas Ilmu Sosial dan Ilmu Politik Universitas Indonesia, 2002), 11.

${ }^{20}$ Ade ma'aruf, Solilqui, Pemikiran Filsafat, Agama dan Politik, (Yogyakarta: Jendela. 2002), 147.

${ }^{21}$ Denny JA, Menjelaskan Gerakan Mahasiswa. (Harian Kompas, 25 April 1998).

${ }^{22}$ Arif Budiman, Peranan Mahasiswa sebagai Intelegensia dalam Cendekiawan dan Politik, edt. Waitamo Soekito, (Jakarta: LP3ES, 1984), 16.
} 
kekuatan pendobrak, ketika terjadi kemacetan dalam sistem politik. ${ }^{23}$ Setelah pendobrakan dilakukan maka adalah tugas kekuatan-kekuatan politik yang ada dalam hal ini partai-partai atau organisasi politik yang lebih mapan yang melakukan pembenahan. Komitmen mahasiswa yang masih murni terhadap moral berdasarkan pergulatan keseharian mereka dalam mencari dan menemukan kebenaran lewat ilmu pengetahuan yang digeluti adalah sadar politik mahasiswa. Karena itu politik mahasiswa digolongkan sebagai kekuatan moral. ${ }^{24}$

\section{FILOSOFI AJARAN DAN HUKUM ISLAM}

\section{Kewajiban Tolong Menolong Kebaikan}

Firman Allah di dalam al-Qur'an:

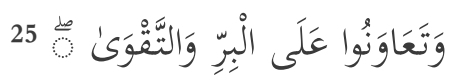

Menurut Ibnu Katsir bahwa Allah swt memerintahkan semua hamba-Nya agar senantiasa tolong menolong dalam melakukan kebaikan-kebaikan yang termasuk kategori Al-Birr dan mencegah dari terjadinya kemungkaran sebagai realisasi dari takwa. Sebaliknya Allah swt melarang dukungan terhadap segala jenis perbuatan batil yang melahirkan dosa dan permusuhan.

Dikisahkan suatu ketika Rasulullah SAW bermusyawarah dengan Abu Bakar dan Umar RA. Pokok pembahasannya adalah menyusun barisan kaum Muslimin serta mempererat persatuan, untuk menghilangkan segala bayangan yang akan membangkitkan api permusuhan lama diantara mereka. Supaya tujuan ini tercapainya maka Rasululloh saw mengajak kaum Muhajirin dan Anshar agar masing-masing bersaudara berdua-dua. Rasul SAW bersaudara dengan Ali bin Abi Thalib. Pamannya Hamzah bersaudara dengan Zaid bekas budaknya. Abu Bakar bersaudara dengan Kharija bin Zaid, Umar ibnu Khattab bersaudara dengan 'Itban bin Malik al-Khazraji. Himbauan Nabi Muhammad SAW ini juga dikuti oleh kaum muslim karena keinginan melaksanakan ayat yang lain;

\footnotetext{
${ }^{23}$ Arif Budiman, Catatan Kritis Mencoba Memahami Si Bintang Lapangan 1998, dalam Arbi Sanit, Pergolakan Melawan Kekuasaan, (Yogyakarta: Pustaka Pelajar, 1999) hlm. Xvi. Lihat juga: Arbi Sanit, Reformasi Politik. (Yogyakarta: Pustaka Pelajar, 1998), 267.

${ }^{24}$ Arbi Sanit, Reformasi Politik, 267

${ }^{25}$ Al-Maidah (5):2.
} 


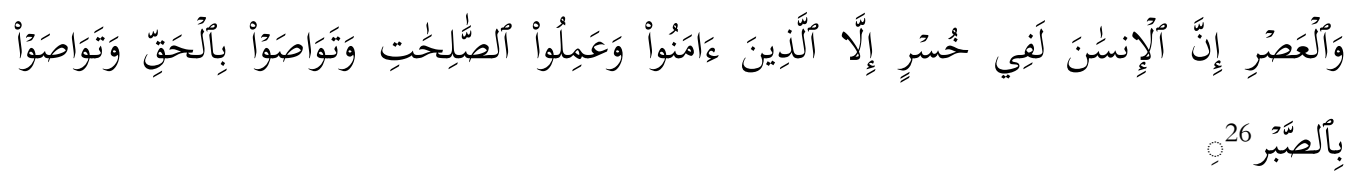

Surat Al-'Ashr mendorong pengembangaan sifat insaniyah individual, tetapi juga kewajiban untuk membentuk masyarakat insaniyah atau masyarakat yang memiliki sifat kemanusiaan. Al-Qur'an tidak mengguna-kan kata tanãshahû (saling memberi nasihat), tetapi Al-Qur'an menggunakan kata "saling memberi wasiat". Wasiat itu lebih dari sekedar nasihat. Nasihat itu boleh dilaksanakan boleh tidak, mungkin juga boleh didengar atau tidak, akan tetapi kalau wasiat harus didengar dan dilaksanakan.

Kata tawãshau bil haq kita menggabngkan subyek, tetapi sekaligus objek. Kita selain menerima wasiat, jugadiberi wasiat. Apa yang harus diwasiat-kan? Al-Haqq dan Ash-Shabr. Sebagaimana iman tidak bisa dipisahkan dengan amal saleh, maka Al-Haqq tidak bisa dipisahkan dengan Ash-Shabr. Jadi orang tidak dikatakan beriman kalau tidak beramal saleh dan tidak dikatakan membela kebenaran kalau tidak tabah dalam membela kebenaran itu. Surah ini Allah mengajarkan kepada kita semua termasuk mahasiswa bahwa kita berada pada tingkat yang rendah atau dalam kerugian apabila tidak mengembangkan diri dengan iman dan amal saleh. Gerakan mahasiswa juga menjadi gerakan yang rendah bilatidak menegakkan Al-Haq dan Ash-Shabr di tengahtengah masyarakat kita.

\section{Amar Ma'ruf Nahi Munkar}

Setelah Rasulullah Saw. diutus, maka umat yang mengikuti seruan Rasulullah Saw. adalah sebaik-baiknya umat.Mereka mendapatkan petunjuk dari Allah SWT. melalui Rasulullah SAW, hal ini difirmankan oleh Allah SWT dalam surah Ali Imron ayat 110 :

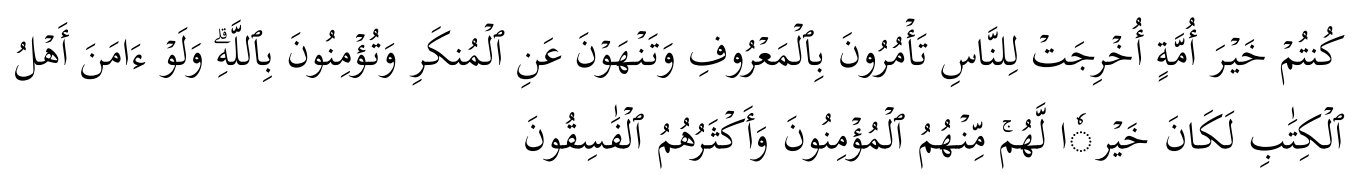

Ayat ini menjelaskan bahwa umat Nabi Muhammad Saw.adalah umat yang terbaik, sebab selain mengikuti Nabi Muhammad Saw. mereka juga melakukan amar ma'ruf nahi mungkar. Firman Allah “kuntum khaira ummah”, menurut Imam Bukhari: dari Muhammd Bin Yusuf, dari Sufyan Ibn Maysarah, dari Abi Haazim dari Abi

${ }^{26}$ Al-'Asr (103):1-3 
Hurairah Ra, (kuntum khairo ummah ukhrijat linnas) berkata: "Sebaik-baik manusia untuk manusia yang lain yaitu datang kepada mereka dengan terbelenggu leher-leher mereka sampai mereka masuk ke dalam Islam, dan seperti ini yang dikatakan oleh Abu Hurairah, Mujahid dan 'Ithiyah al-'Ufi. Dapat berarti pula sebaik-baik manusia yang bermanfaat bagi manusia yang lainnya". Pada lainnya, Rasulullah mengemukakan sebaik-baik manusia yang pandai diantara mereka dan paling bertakwa diantara mereka, dan menyuruh mengerjakan yang ma'ruf, dan mencegah mereka dari perbuatan yang munkar, menyambung tali silaturahmi. ${ }^{27}$

Dalil lain yang menerangkan kewajiban tentang ber-amar ma'ruf nahi mungkar, yang tertuang pada surat Ali Imran ayat 104 yang artinya,

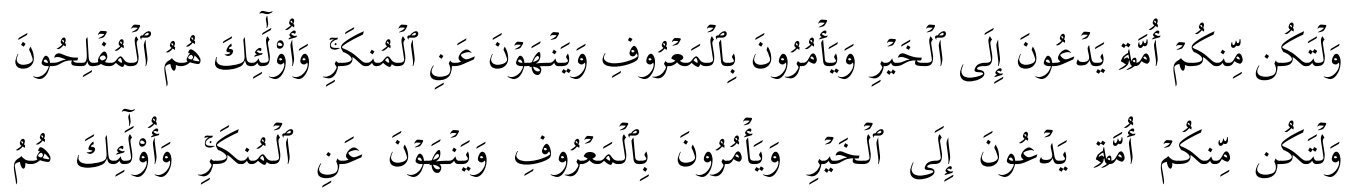

Ayat ini menghendaki ada segolongan manusia yang menjalankan perintah Allah untuk berjuang dalam da'wah kepada kebaikan dan menyuruh mengerjakan perbuatan yang ma'ruf serta mencegah dari pada yang kemungkaran. ${ }^{29} \mathrm{Abu}$ Ja'far berkata: waltakum minkum: ayat itu berarti "wahai orang-orang beriman", "Ummah" bermakna “jama' ah", ${ }^{30}$ lalu ila al-khair. kepada Islam dan syari' atnya" ${ }^{31}$

Sementara kata minkum dalam tafsiral-Qurthubi "Al-Jami'al-Ahkamal-Qur'an" perintah untuk melakukan pekerjaan ini dikhususkan kepadaorang-orangyang berilmu, danmanusia tidak semuanya berilmu. ${ }^{32}$ Rasulullah saw bersabda: "Apa kamu melihat kemungkaran hendaklah merubahnya dengan tangannya, jika tidak mampu maka rubahlah dengan lisannya, jika tidak mampu maka rubahlah dengan hatinya (yakni tidak menyukai perbuatan tersebut)."33

\footnotetext{
${ }^{27}$ Abi Abdullah Muhammad Ibn Abu Al-Qurthubi, Al-Jami’ Al-Ahkam Al-Qur'an, Juz 5,(Beirut Lebanon: Muassasah Ar- Risalah, 2006 M/ 1427 H), 344.

${ }^{28}$ Ali Imron: 104

${ }^{29}$ Ibnu Katsir, Tafsir Al-Qur'an Al- 'Adzim, Tt, Maktabah Al-'Asriyah, Jilid I,2000M/1420H, 342

${ }^{30}$ Abdurahman An-Nashir As-Sa'di, "Taisir Al-Karim Ar-Rahman Fi Tafsir Kalam Al-Mannan”, Beirut Lebanon: Jami’ Al-Huquq Mahfudzah, 2002 M/ 1423 H, 142

${ }^{31}$ Ath Thabari, “Jami' Al-Bayan Fi Tafsir Al-Qur'an", (Kairo: Maktabah Hajr, 2001), 89.

${ }^{32}$ Abi Abdullah Muhammad Ibn Abu Al-Qurthubi, Al-Jami' Al-Ahkam Al-Qur'an, (Beirut Lebanon: Muassasah Ar- Risalah, 2006 M/ 1427 H), Juz 5, 253

${ }^{33}$ Abi Abdullah Muhammad Ibn Abu Al-Qurthubi, Al-Jami' Al-Ahkam Al-Qur'an, 254.
} 
Ada dua pendapat tentang surah Ali Imron ayat 104 tersebut yaitu kewajiban Amar ma'ruf nahi munkar. Pendapat yang pertama, bahwa perintah untuk ber-amar ma'ruf nahi mungkar adalah sebuah kewajiban bagi setiap Muslim, bukan hanya pemerintah ataupun perwakilan, tetapi setiap individu memiliki kewajiban ber-amar ma'ruf nahi mungkar. Ketikadihadapan mahasiswa ada sebuah kemungkaran, kedholiman bahkan ketidak adilan maka mahasiswa wajib untuk melarangnya, jangan sampai dibiarkan, malah ini akan menjadi beban tersendiri, yang harus ditanggung.

Pendapat kedua, bahwa makna perintah dari ayat di atas adalah fardhu kifayah, bukan kewajiban bagi setiap individu. Jika sudah ada sebuah kelompok atau perwakilan yang memerintahkan untuk berbuat kebajikan dan menjauhi kemungkaran, maka gugurlah kewajiban orang lain yang belum menyeru Amar ma'ruf nahi munkar. Fardhu kifayah adalah apabila salah seorang sudah melaksanakan maka gugurlah kewajiban kepada orang yang lain.

\section{Kewajiban Mengadakan Perbaikan}

Islam datang guna mewujudkan kemashlahatan dan bahkan menyempurnakannya. Disamping itu, Islam datang juga bertujuan menghilangkan segala madharat atau menguranginya. Hal tersebut menjadi salah satu karakteristik Islam yang sangat menonjol dan menjadi penciri Islam dengan agama lain. Sebagai contoh misalnya adanya himbuan untuk memperbaiki dan sekaligus melarang adanya kerusakan yang ada di muka bumi dan ditekankan dalam berbagai ayat, misalnya dalam firman-Nya surah al-'Araf ayat 56:,

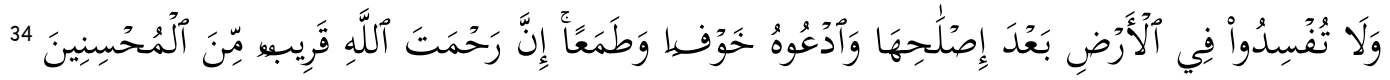

Ajaran Islam benar-benar mengutuk adanya kerusakan yang dilakukan oleh manusia di bumi, hal tersebut dijelaskan dalam ajarannya mengenai berbagai macam perbuatan kerusakan yang tidak selaras dan senafas dengan nilai-nilai Islam yang mulia.

\section{KESIMPULAN}

Secara historis Islam telah meletakkan dasar-dasar hukum dan nilai-nilai pergerakan bagi ummatnya. Islam hadir dengan berbagai perangkat tersebut, oleh karena itu, penting kiranya pergerakan mahasiswa yang merupakan pergerakan moral mengacu

\footnotetext{
${ }^{34} \mathrm{Al}-{ }^{`} \operatorname{araf}(7): 56$
} 
pada nilai-nilai yang telah digariskan oleh Islam. Artikel ini juga menyimpulkan bahwasannya pergerakan mahasiswa adalah "kekuatan moral" dan bukannya "kekuatan politik". Disamping nilai-nilai Islam, nilai moral dan dasar-dasar pedoman dan kearifan lokal juga perlu menjadi perhatian tersendiri bagi pergerakan mahasiswa utamanya di era perkembangan teknologi dan revolusi digital yang sekarang sedang massif terjadi.

\section{DAFTAR PUSTAKA}

A. R. Evyta. 2005. Gerakan Mahasiswa antara Idealitas dan Realitas. Medan: KAMMI. Al-Qurthubi, Abi Abdullah Muhammad Ibn Abu. 2006. Al-Jami' Al-Ahkam Al-Qur'an,

Juz 5. Beirut Lebanon: Muassasah Ar- Risalah.

As-Sa'di, Abdurahman An-Nashir. 2002. Taisir Al-Karim Ar-Rahman Fi Tafsir Kalam AlMannan, Beirut Lebanon: Jami’ Al-Huquq Mahfudzah.

Budiman, Arif. 1984. Peranan Mahasiswa sebagai Intelegensia dalam Cendekiawan dan Politik. Ed. Waitamo Soekito. Jakarta: LP3ES.

Budiyarso, Edy. 2000. Menentang Tirani: Aksi Mahasiswa 77/78. Jakarta: Grasindo Denny JA. 1998. Menjelaskan Gerakan Mahasiswa. Harian Kompas, 25 April. Katsir, Ibnu. 2000. Tafsir Al-Qur'an Al- 'Adzim. Maktabah Al-'Asriyah, Jilid I.

Pramusinto, Agus \& Yuyun Purbokusumo. 2016. Indonesia Begerak 2. Yogyakarta: Institute of Governance and Public Affair (IGPA) Magister Administrasi Publik (MAP) Universitas Gadjah Mada.

Prasetyantoko A. \& Indrio, Ign. Wahyu, dkk. 2001. Gerakan Mahasiswa dan Demokrasi di Indonesia. Jakarta: Kompas.

Putrayasa, Ida Bagus. 2012. Landasan Pembelajaran. Bali: Undiksha Press.

Sanit, Arbi. 1999. Pergolakan Melawan Kekuasaan; Gerakan Mahasiswa Antara Aksi Moral dan Politik, Yogyakarta: Pustaka Pelajar. 1998. Reformasi Politik. Yogyakarta: Pustaka Pelajar.

Solilqui, Ade Ma'aruf. 2002. Pemikiran Filsafat, Agama dan Politik. Yogyakarta: Jendela.

Suwondo. 2002. Gerakan Mahasiswa Bandar Lampung. Jakarta: Bidang Studi Ilmu Politik Program Pasca Sarana Fakultas Ilmu Sosial dan Ilmu Politik Universitas Indonesia.

Thabari, Ath. 2001. Jami’ Al-Bayan Fi Tafsir Al-Qur'an. Kairo: Maktabah Hajr.

Usman, Sunyoto. 1999. Arah Gerakan Mahasiswa: Gerakan Moral ataukah Gerakan Politik. Jurnal Imu Sosial \& Ilmu Politik, vol. 3, no. 2. 